\section{POTREBA ZA SUPERVIZIJOM ŠKOLSKIH PSIHOLOG(INJ)A U HRVATSKOJ}

Cilj istraživanja bio je utvrditi dosadašnje iskustvo školskih psiholog(inj)a sa supervizijom i potrebu za takvim oblikom profesionalne podrške. $U$ istraživanju je sudjelovalo 149 školskih psiholog(inj)a koji su dobrovoljno ispunili online anketu. Psiholozi/ginje koji rade isključivo u nastavi nisu bili obuhvaćeni ovim istraživanjem. Rezultati pokazuju kako $70 \%$ sudionika/ca procjenjuje visokim svoje znanje o superviziji. Jednako tako, $66 \%$ sudionika/ca ima iskustvo s nekim oblikom supervizije, no svega $22 \%$ prisustvovalo ih je superviziji namijenjenoj specifično školskim psiholozima/ginjama. Oko $80 \%$ ispitanih psiholog(inj)a procjenjuje visokim svoju potrebu za supervizijom, a svega $5 \%$ smatra kako im supervizija nije potrebna. Psiholozi/ginje koji imaju iskustvo supervizije, značajno se ne razlikuju po potrebi za supervizijom od onih koji to iskustvo nisu imali. Utvrđeno je da postoji pozitivna značajna povezanost između procjene stupnja profesionalne osamljenosti $i$ potrebe za supervizijom. Prema očekivanju, motivacija

1 Maja Kolega, psihologinja, e-mail:maja.kolega@vern.hr

2 Prof. dr. sc. Vesna Vlahović-Štetić, psihologinja, e-mail: vvlahovi@ffzg.hr

Stručni članak

Primljeno: prosinac, 2013.

Prihvaćeno: travanj, 2014.

UDK $159.942: 304.3$

DOI 10.3935/ljsr.v21i2.16

Maja Kolega ${ }^{1}$

Veleučilište VERN'

Zagreb

Vesna Vlahović-

Štetić ${ }^{2}$

Odsjek za psihologiju

Filozofski fakultet Sveučilišta

u Zagrebu

Ključne riječi:

supervizija, školski psiholozi/ ginje, stručno usavršavanje. 
psiholog(inja) za uključivanje u superviziju vrlo je visoka ako je supervizija dio radnog vremena, ako bi se održavala u mjestu stanovanja te ako je za polaznike/ce besplatna.

\section{UVOD}

Supervizija je proces specifičnog učenja i razvoja u kojem osoba vlastitim iskustvom usvaja nove profesionalne i osobne uvide. Opće je prihvaćeno stajalište kako je supervizija nužna u profesionalnom radu i razvoju svih stručnjaka koji neposredno rade s ljudima. Osnovna je svrha supervizije ohrabriti ljude da pronađu vlastiti stil rada te da mogu birati način ponašanja u susretu s klijentima. Postoje mnogi modeli supervizije, i za sada nema jedinstvenog određenja ovog pojma. Prema Ajduković i Cajvert (2001.: 19), supervizija se određuje kao:

»(..) proces razvoja stručnjaka kao reflektirajućeg praktičara. Proces supervizije stvara kreativni prostor u kojem stručnjak integrira teoriju i praksu, u kontaktu je s potrebama klijenta, ali i svojim vlastitim osjećajima, svjestan resursa i ograničenja klijenta, samog sebe i okruženja u kojem se susreću i tako stvara pretpostavke da funkcionira kao profesionalna osoba u punom smislu te riječi. Na taj način supervizija postaje i garancija kvalitetnog rada s klijentom.«

lako ne postoji velik broj istraživanja iz tog područja, potvrđena je povezanost sudjelovanja u superviziji sa zadovoljstvom poslom kod stručnjaka iz područja mentalnog zdravlja (Schroffel 1999.; Crutchfield i Borders, 1997., prema Thielking, Moore i Jimerson, 2006.).

Kako su na mjestu školskog psihologa uglavnom zaposlene žene, u radu je nadalje korištena ženska inačica zanimanja (npr. školske psihologinje) koja podrazumijeva oba spola.

\section{Supervizija školskih psihologinja}

Superviziju psihologijskih usluga u školama McIntosh i Phelps (2000. : 33) definiraju kao »međusobnu interakciju dviju ili više osoba s ciljem dijeljenja znanja, poboljšanja profesionalnih kompetencija i pružanja objektivne povratne informacije s krajnjim ciljem razvoja novih kompetencija, olakšavanja učinkovitog pružanja psihologijskih usluga i održavanja profesionalnih kompetencija«.

Neki autori (Borders i Usher, 1992., prema Przytula, 2007.) napominju kako školske psihologinje imaju najmanje mogućnosti sustavne supervizije u usporedbi sa stručnjacima iz drugačijih savjetodavnih okruženja (primjerice klinike, obiteljskih savjetovališta i sl.).

\section{6 članci}


Mnogo školskih psihologinja osjeća se profesionalno izolirano i s nedostatnom podrškom u svojoj ulozi (Harvey i Struzziero, 2008.; Bloomquist, 2007.). Kako bi to naglasili, Boyd i Walter (1975., prema Dunn, 2004. : 103) uspoređuju posao školskih psihologinja s »kaktusom koji preživljava na minimalnim hranjivim sastojcima iz okoline«, smatrajući upravo superviziju vitalnim hranjivim sastojkom.

Učinkovita supervizija školskih psihologinja doprinosi zadovoljstvu poslom i smanjenju stresa, smanjuje profesionalnu izolaciju, sprečava sagorijevanje i psihološko ili fizičko povlačenje s posla te poboljšava stručno rješavanje problema (Harvey i Pearrow, 2010.). Coster i Schwebel (1997.) intervjuirali su iskusne i uspješne psihologinje u svom području. Prema njihovim iskazima, sustručnjačka podrška i supervizija procijenjene su važnim činiteljima za njihovo uspješno profesionalno djelovanje. Školske psihologinje bez supervizije mogu postati manje sigurne u svoje vještine te razina njihovih vještina s vremenom opada (Peace, 1995., prema Dunn, 2004.). S druge strane, kod psihologinja uključenih u superviziju primijećen je porast percipirane samoefikasnosti i učinkovitosti pružanja usluga (Borders, 1991.a; Cashwell i Dooley, 2001.; Henderson i Lampe, 1992.; Peace, 1995., sve prema Dunn, 2004.). Prema istraživanju Pietrzaka i Suttona (2001., prema Linton i Deuschle, 2006.), školske psihologinje vide superviziju u prvom redu kao pomoć u radu s učenicima te za razvoj novih vještina i tehnika.

Uz to, najznačajnija dobit od supervizije je profesionalna podrška. To je posebno značajno za psihologinje koje rade u izoliranom okruženju. U nemogućnosti dobivanja sustavne supervizije one često koriste neformalnu sustručnjačku mrežu za profesionalnu podršku i savjet (Ross i Goh, 1993., prema Ward, 2001.). Istraživanja uglavnom potvrđuju višestruku korisnost sustručnjačke (eng. peer) supervizije (Çoban, 2004.; McMahon, 2002.).

Sustavno pomanjkanje supervizije za školske psihologinje uočava se čak i u razvijenim zemljama poput Sjedinjenih Američkih Država (Harvey i Struzziero, 2008.; McIntosh i Phelps, 2000.). Kod provođenja supervizije istaknut je općenito nedostatan broj kvalificiranih supervizora i pomanjkanje motivacije psihologinja za kliničkom supervizijom. Kako ne postoji dovoljan broj iskusnih i educiranih supervizora, superviziju često provode nedovoljno kvalificirani stručnjaci, što smanjuje motivaciju za sudjelovanjem (Crespi i Fischetti, 1997.). Bloomquist (2007.) je u svojem istraživanju dobila rezultate koji pokazuju da školske psihologinje koje superviziraju mlade kolegice - pripravnice imaju značajno veći stupanj zadovoljstva poslom od onih koje nisu uključene u takve aktivnosti.

Poznato je da je socijalna podrška jedan od važnih činitelja koji pomaže pojedincu u nošenju sa stresnim situacijama. Huebner (1993.) je na uzorku školskih psihologinja pokazao kako upravo socijalna podrška, posebno supervizijska podrška, doprinosi zadovoljstvu poslom. Autor naglašava važnost sustavne supervizije 
u školama, naglašavajući kako je svega nekolicina psihologinja uključena u takav oblik stručnog usavršavanja. Iste rezultate dobila je i Przytula (2007.): školske psihologinje zadovoljne kvalitetom i količinom dobivene supervizije pokazuju veće opće zadovoljstvo poslom.

\section{Supervizija u Republici Hrvatskoj}

U našoj zemlji supervizija kao oblik rada s pomagačima postoji duže vremena u kliničkom okruženju. Tijekom i nakon rata provođeni su mnogi psihosocijalni projekti u okviru kojih se također provodio neki njezin oblik.

U područje obrazovanja supervizija je ušla još 1999. godine kada je psihologinja Mirjana Šimunović-Škunca započela provođenje integrativne supervizije u sklopu djelatnosti aktiva razrednika (Bokulić, 2003.). Uvođenje sustavnije supervizije nastavnog osoblja potaknuto je tragedijom 2003. godine u Varaždinu kada je učenik u školskom dvorištu ubio profesora i sebe (Pregrad, 2006.). Društvo za psihološku pomoć ponudilo je nastavnicima varaždinske škole paket od četiri dvodnevna seminara i pet supervizijskih susreta u malim grupama tijekom jedne godine. Projekt je završen 2006. godine, ponajprije zbog nedostatka financija.

U formalnijem obliku supervizija je ušla u područje obrazovanja 2005. godine, projektom Jačanje kapaciteta za integrativnu superviziju u Agenciji za odgoj i obrazovanje, u okviru programa PHARE. Dvogodišnjom edukacijom (2007.-2009.) osposobljeno je petnaest viših savjetnica Agencije koje su izradile Protokol za uvođenje supervizije u odgojno-obrazovni sustav (Skelac, 2008.). Time je supervizija ušla u katalog stručnih skupova namijenjenih djelatnicima iz područja odgoja i obrazovanja. U razdoblju od 2008. do 2011. godine čak 780 djelatnika odgojno-obrazovnog sustava sudjelovalo je u superviziji (Ozorlić Dominić i Skelac, 2011.).

Pregrad i Krivičić Jedrejčić (2012.) provele su opsežno istraživanje o iskustvima u primjeni supervizije u sustavu odgoja i obrazovanja iz perspektive supervizanata i supervizora. Čak $96 \%$ ispitanih prosvjetnih djelatnika smatra potrebnim uvođenje supervizije u sustav odgoja i obrazovanja. Korist od supervizije vide prvenstveno za podizanje kvalitete profesionalnog rada, osobni rast i razvoj te stjecanje novih znanja i vještina.

Veliko je postignuće što je supervizija prepoznata kao oblik usavršavanja djelatnika u obrazovanju te je uvrštena u katalog stručnih skupova Agencije za odgoj i obrazovanje. Može se očekivati kako će u budućnosti postati sastavni dio profesionalnog usavršavanja svih djelatnika u obrazovanju.

\section{8 članci}




\section{CILJ ISTRAŽIVANJA}

Osnovni cilj ovog istraživanja bio je utvrditi dosadašnje iskustvo školskih psihologinja sa supervizijom te potrebu za takvim oblikom stručnog usavršavanja.

Iz tako postavljenog cilja proizlaze četiri problema istraživanja:

1. utvrditi dosadašnje iskustvo školskih psihologinja za supervizijom i trenutnu uključenost u neki oblik supervizije

2. istražiti povezanost između nekih obilježja uzorka (godina staža, procijenjene profesionalne osamljenosti) i iskazane potrebe za supervizijom

3. utvrditi motivaciju za uključivanjem u superviziju i/ili obrazovanjem za supervizora

4. utvrditi najčešće probleme na poslu s kojim bi se uključile u superviziju.

METODA

\section{Sudionice i postupak istraživanja}

Uzorak čini 149 sudionica, što je otprilike 50\% ukupne populacije školskih psihologa u trenutku ispitivanja u Republici Hrvatskoj. Od tog broja, 92\% uzorka čine žene, a svega $8 \%$ muškarci. Prosječna starost sudionika/ca u istraživanju je 38 godina, a 9 godina je prosjek radnog staža provedenog na mjestu školskog psihologa. U gradskoj sredini radi $81 \%$ sudionica, a 19\% u naselju ili na selu. Najviše sudionica je iz područja Grada Zagreba (22\%).

Uzorak istraživanja čine one školske psihologinje koje su ispunile online upitnik poslan na adrese svih školskih psihologinja u Hrvatskoj u razdoblju od 16. 06. do 04. 08. 2011. godine. Psihologinje koje rade samo u nastavi nisu obuhvaćene ovim istraživanjem.

Upitnik je elektroničkom poštom poslan na otprilike 300 adresa u dva navrata: prvi put sredinom lipnja, nakon završetka nastavne godine i početkom srpnja, netom prije godišnjih odmora. Predviđeno vrijeme ispunjavanja upitnika bilo je 20 minuta.

\section{Upitnici}

Za potrebe istraživanja, osmišljen je anketni upitnik s deset pitanja koja se odnose na demografska obilježja školskih psihologinja. Uz pitanja o dobi, spolu, godinama staža, županiji i mjestu u kojem rade te dodatnim edukacijama, neka pitanja odnosila su se i na značajke njihovog radnog mjesta. Tim pitanjima od su- 
dionica se tražilo da navedu koliko učenika pokriva njihovo radno mjesto, koje sve poslove obavljaju na mjestu školskog psihologa i koliko su osobno motivirane za obavljanje tih poslova. Zadnja dva pitanja odnosila su se na procjenu zadovoljstva poslom, odnosima sa stručnom službom škole i institucijama s kojima surađuju, te procjenu stupnja profesionalne osamljenosti na radnom mjestu.

Primijenjen je i anketni upitnik o dosadašnjem znanju, iskustvu i potrebi školskih psihologinja za supervizijom koji sadrži devet pitanja. Pitanjima se željelo ispitati kako psihologinje procjenjuju svoje znanje o superviziji, imaju li iskustva sa supervizijom i jesu li u ovom trenutku uključene u neki oblik supervizije. Tražila se također procjena njihove potrebe za supervizijom. Za psihologinje koje imaju iskustvo sa supervizijom tražena je procjena koristi od supervizije s obzirom na dvanaest različitih aspekata. Jednako tako, pitanjima se željelo saznati kolika je motivacija školskih psihologinja za uključivanjem u superviziju i za edukaciju za supervizora. Otvorenim pitanjem željelo se saznati s kakvim se problemima, pitanjima ili dilemama najčešće susreću na svom radnom mjestu, a za koje smatraju da bi im supervizija mogla koristiti.

Upitnici su osmišljeni za uzorak školskih psihologa, a kao predložak za pojedina pitanja i radi lakše usporedbe korišten je upitnik za psihologe u službama mentalnog zdravlja (Mesić i Ajduković, 2010.).

\section{REZULTATI I RASPRAVA}

Rezultati iz tablice 1. pokazuju kako $66 \%$ ispitanih psihologinja ima iskustvo nekog oblika supervizije. Ipak, svega $22 \%$ sudionica iskazuje kako je prisustvovalo nekom obliku supervizije namijenjene specifično školskim psihologinjama.

Tablica 1. Iskustvo i trenutna uključenost školskih psihologinja u neki oblik supervizije

\begin{tabular}{lcccccc}
\hline \multirow{2}{*}{$\begin{array}{l}\text { Iskustvo sa } \\
\text { supervizijom }\end{array}$} & \multicolumn{2}{c}{ Općenito } & \multicolumn{2}{c}{ Za šk. psih. } & \multicolumn{2}{c}{$\begin{array}{l}\text { Trenutna } \\
\text { uključenost }\end{array}$} \\
\cline { 2 - 8 } & $\mathbf{N}$ & $\%$ & $\mathbf{N}$ & $\%$ & $\mathbf{N}$ & $\%$ \\
\hline $\mathrm{Ne}$ & 48 & 32,21 & 115 & 77,18 & 125 & 83,89 \\
\hline $\mathrm{Da}$ & 99 & 66,44 & 32 & 21,48 & 22 & 14,77 \\
\hline Neodgovoreno & 2 & 1,34 & 2 & 1,34 & 2 & 1,34 \\
\hline Ukupno & 149 & 100 & 149 & 100 & 149 & 100 \\
\hline
\end{tabular}

Iz prikupljenih podataka vidljivo je kako iskustvo supervizije imaju uglavnom one psihologinje koje su ga stekle tijekom psihoterapijskog obrazovanja, dok se supervizija namijenjena specifično školskim psihologinjama vjerojatno organizi- 
rala sporadično. Budući da nema službenih podataka o sustavnoj superviziji namijenjenoj psihologinjama u školama, može se pretpostaviti da su psihologinje organizirale supervizijske susrete na vlastitu inicijativu. Svega 15\% psihologinja trenutno je uključeno u neki oblik supervizije. Iz odgovora nije jasno o kakvom se obliku supervizije radi. Uočljivo je da sve ispitanice, uključene u neki oblik supervizije, imaju ujedno i obrazovanje iz najmanje jednog terapijskog smjera. $\mathrm{Na}$ temelju toga može se pretpostaviti da se radi o superviziji u sklopu neke edukacije ili savjetodavne prakse.

Prema dobivenim rezultatima, $71 \%$ psihologinja procjenjuje vrlo visokim svoje znanje o superviziji. Na temelju ovog istraživanja nije moguće procijeniti kvalitetu znanja o superviziji, odnosno jesu li znanja koja sudionice imaju sukladna s konceptom razvojno-integrativne supervizije. Može se pretpostaviti da je većina psihologinja čula za superviziju, no nema jasnu sliku o tome kako taj proces izgleda u praksi. Nema mnogo licenciranih supervizora iz razvojno-integrativne supervizije i može se pretpostaviti da su većinu iskustava sa supervizijom sudionice stekle psihoterapijskim obrazovanjem ili suradnjom s nevladinim sektorom.

Oko $80 \%$ ispitanih psihologinja procjenjuje visokim svoju potrebu za supervizijom, a svega $5 \%$ smatra kako im supervizija nije potrebna. Za usporedbu, djelatnici u sustavu odgoja i obrazovanja koji imaju iskustvo supervizije u $96 \%$ slučajeva smatraju potrebnim uvođenje supervizije u sustav (Pregrad i Krivičić Jedrejčić, 2012.). Smatramo da se iz tih podataka može zaključiti kako je važno direktno iskustvo sa supervizijom jer s njime postaju vidljive dugotrajne prednosti takvog oblika rada.

Prema rezultatima, školske psihologinje najviše koristi od supervizije vide u pomoći pri rješavanju težih slučajeva i razjašnjavanju nekih profesionalnih dilema. Na visokom mjestu je i dobivanje povratne informacije o kvaliteti rada. Prema Bezić (2007.), stručnjaci često dolaze na superviziju s ciljem dobivanja potvrde za svoj rad. Nemaju supervizijsko pitanje, nego očekuju povratnu informaciju na temelju onog što su izložili. Takav proces nije supervizijski, nego više podsjeća na ispitnu situaciju u kojoj očekujemo potvrdu i ocjenu za dobro obavljen posao. Cilj supervizije je nova, kreativna kvaliteta koja će obogatiti rad supervizanta, a ne potvrda ili procjena njegovog rada. Moguće je da već sama riječ »supervizija« pobuđuje asocijacije na procjenu i neki oblik nadzora, pogotovo kod stručnjakinja koje nikada nisu imale iskustvo s takvim oblikom profesionalnog razvoja.

U tablici 2. prikazani su neki aspekti koristi od supervizije, kako je vide školske psihologinje. Korist su sudionice procjenjivale na skali od 1 - vrlo malo do 5 - vrlo mnogo. 
Tablica 2. Aspekti procijenjene koristi od supervizije (aritmetičke sredine (M), standardne devijacije (SD), raspon odgovora (min., max., $\mathrm{N}=149$ )

\begin{tabular}{lllll}
\hline Aspekti koristi od supervizije & M & SD & Min. & Max. \\
\hline $\begin{array}{l}\text { Pomoć u rješavanju težih } \\
\text { slučajeva }\end{array}$ & 4,62 & 0,84 & 1 & 5 \\
\hline $\begin{array}{l}\text { Razjašnjavanje nekih } \\
\text { profesionalnih dilema }\end{array}$ & 4,90 & 0,74 & 1 & 5 \\
\hline $\begin{array}{l}\text { Dobivanje povratne informacije } \\
\text { o kvaliteti rada }\end{array}$ & 4,31 & 0,89 & 1 & 5 \\
\hline $\begin{array}{l}\text { Smanjivanje negativnih učinaka } \\
\text { stresa }\end{array}$ & 4,13 & 1,10 & 1 & 5 \\
\hline $\begin{array}{l}\text { Poboljšanje kvalitete rada s } \\
\text { korisnicima }\end{array}$ & 3,97 & 0,93 & 1 & 5 \\
\hline $\begin{array}{l}\text { Razvoj profesionalnih vještina } \\
\text { Smanjivanje osjećaja } \\
\text { profesionalne usamljenosti }\end{array}$ & 3,93 & 1,07 & 1 & 5 \\
\hline $\begin{array}{l}\text { Unapređenje timskog rada i } \\
\text { kom. s kolegama }\end{array}$ & 3,91 & 1,20 & 1 & 5 \\
\hline $\begin{array}{l}\text { Druženje s kolegama } \\
\text { svakodnevnice }\end{array}$ & 3,77 & 1,17 & 1 & 5 \\
\hline \begin{tabular}{l} 
Osobni rast i razvoj \\
\hline
\end{tabular} & 3,57 & 1,09 & 1 & 5 \\
\hline
\end{tabular}

Na zadnjem mjestu po procjeni su odmak od profesionalne rutine i svakodnevnice te osobni rast i razvoj, iako su i ti aspekti procijenjeni relativno korisnima.

Zanimljivo je usporediti rezultate s djelatnicima u sustavu odgoja i obrazovanja koji imaju iskustvo supervizije (Pregrad i Krivičić Jedrejčić, 2012.). Prema njihovim odgovorima, najveći dobici od supervizije su unapređenje profesionalnog rada i osobni rast i razvoj. Kada bi opisivali superviziju koleg(ic)ama koji nisu imali iskustva sa supervizijom, više bi naglašavali osobni rast i razvoj od profesionalnog. Može se pretpostaviti da stručnjaci koji nemaju iskustvo sa supervizijom, najveći fokus korisnosti od supervizije stavljaju na pomoć kod konkretnih problema s kojima se susreću na poslu. $S$ druge strane, stručnjaci koji su imali direktno iskustvo 
supervizije uviđaju koliko su profitirali na osobnom planu te to naglašavaju kao najvažniju dobit.

U projektu uvođenja supervizije u sustav socijalne skrbi (Ajduković, i Ajduković, 2004.), sudionici su, kao najveću dobit sudjelovanja u supervizijskim grupama, naveli samo iskustvo sudjelovanja u grupi (39\%). Odmah zatim slijedi profesionalni i osobni rast i razvoj (24\%). U istraživanjima američkih školskih psihologinja, Roberts i Border (1994., prema Webber, 2004.) pokazali su da 80\% sudionica kao prioritete supervizije vide profesionalni razvoj i profesionalnu podršku, a više od polovice superviziju smatra podrškom za prevenciju sagorijevanja. U istom uzorku, 75\% sudionica izražava potrebu za supervizijom, dok svega $15 \%$ ima iskustva s kliničkom (razvojno-integrativnom) supervizijom.

\section{Neka obilježja uzorka i potreba za supervizijom}

Evaluacija učinka sudjelovanja u superviziji u sustavu socijalne skrbi pokazala je kako je najvažniji aspekt sudjelovanja u superviziji povećanje samopouzdanja, bolja komunikacija u radnom okruženju i manja razina doživljenog stresa na poslu (Ajduković, i Ajduković, 2004.).

U evaluaciji učinka supervizije u sustavu socijalne skrbi, Ajduković, M. i Ajduković, D. (2004.) pokazali su da bi polaznici supervizije/supervizanti htjeli redovitu superviziju znatno češće od kolega koji nisu imali to iskustvo. Oni koji nemaju to iskustvo češće iskazuju potrebu za supervizijom po potrebi, odnosno kad imaju neki teži slučaj.

U ovom istraživanju školskih psihologinja ta se razlika nije pokazala. T-test za nezavisne uzorke pokazao je da se psihologinje koje imaju iskustvo supervizije značajno ne razlikuju po potrebi za supervizijom od onih koje to iskustvo nisu imale $(\mathrm{t}=0,805, \mathrm{p}>0,05)$.

lako se moglo pretpostaviti da će potreba za supervizijom rasti, što su sudionice zadovoljnije poslom, zadovoljstvo poslom nije se pokazalo značajno povezanim s potrebom za supervizijom ( $r=-0,17, p>0,05)$.

$U$ našem uzorku pronađena je statistički značajna razlika između psihologinja koje rade u selu/naselju i onih koje rade u gradu u osjećaju profesionalne osamljenosti. Temeljem toga, mogla se pretpostaviti razlika u iskazanoj potrebi za supervizijom između te dvije skupine psihologinja. Ipak, razlika se nije pokazala statistički značajnom ( $t=1,428 ; p>0,05)$. Jednako tako, nije utvrđena statistički značajna razlika niti u potrebi za supervizijom među psihologinjama iz različitih županija $(F=1,864 ; p>0,05)$. Ipak, pokazalo se da postoji pozitivna značajna povezanost između procjene stupnja profesionalne osamljenosti i potrebe za supervizijom $(r=0,22, p<0,01)$. 


\section{Spremnost za uključivanjem u superviziju i obrazovanjem}

\section{za supervizora}

Procjena motivacije školskih psihologinja za uključivanjem u superviziju istražila se pitanjem jesu li se spremne uključiti u supervizijsku grupu ako bi se supervizija organizirala u sklopu njihovog radnog/slobodnog vremena, ako bi se supervizija organizirala u njihovom mjestu/drugom mjestu i ako bi za njih supervizija bila besplatna ili kad bi same snosile troškove.

Odgovori na pitanje o spremnosti uključivanja u superviziju prikazani su u tablici 3.

Tablica 3. Procijenjena spremnost sudionica za uključivanjem u superviziju s obzirom na različite činitelje

\begin{tabular}{|c|c|c|c|c|c|c|c|c|c|c|c|c|}
\hline & \multicolumn{2}{|c|}{$\begin{array}{l}\text { Radno } \\
\text { vrijeme }\end{array}$} & \multicolumn{2}{|c|}{$\begin{array}{l}\text { Slobodno } \\
\text { vrijeme }\end{array}$} & \multicolumn{2}{|c|}{$\begin{array}{c}\text { Mjesto } \\
\text { stanovanja }\end{array}$} & \multicolumn{2}{|c|}{ Drugi grad } & \multicolumn{2}{|c|}{ Besplatna } & \multicolumn{2}{|c|}{$\begin{array}{l}\text { Samostalno } \\
\text { financiranje }\end{array}$} \\
\hline & $\mathbf{N}$ & $\%$ & $\mathbf{N}$ & $\%$ & $\mathbf{N}$ & $\%$ & $\mathbf{N}$ & $\%$ & $\mathbf{N}$ & $\%$ & $\mathbf{N}$ & $\%$ \\
\hline $\mathrm{Da}$ & 125 & 83,89 & 88 & 59,06 & 139 & 93,29 & 60 & 40,27 & 141 & 94,63 & 17 & 11,41 \\
\hline $\mathrm{Ne}$ & 6 & 4,03 & 18 & 12,08 & 3 & 2,01 & 38 & 25,50 & 3 & 2,01 & 72 & 48,32 \\
\hline Ne znam & 16 & 1,74 & 41 & 27,52 & 5 & 3,36 & 49 & 32,89 & 3 & 2,01 & 58 & 38,93 \\
\hline Neodgov. & 2 & 1,34 & 2 & 1,34 & 2 & 1,34 & 2 & 1,34 & 2 & 1,34 & 2 & 1,34 \\
\hline $\mathrm{N}$ & 149 & 100 & 149 & 100 & 149 & 100 & 149 & 100 & 149 & 100 & 149 & 100 \\
\hline
\end{tabular}

Prema očekivanju, motivacija psihologinja za uključivanje u superviziju vrlo je visoka ako je supervizija dio radnog vremena (84\%), ako bi se održavala u mjestu stanovanja (93\%) te ako je za polaznice besplatna (95\%).

$\mathrm{S}$ druge strane, više od polovice sudionica investiralo bi i svoje slobodno vrijeme za superviziju (59\%), gotovo polovica (40\%) spremna je putovati u drugi grad na superviziju, a svega $11 \%$ spremno je samostalno snositi troškove supervizije. Kako je u pitanjima bio omogućen odgovor »ne znam«, relativno velik broj sudionica izabrao je tu mogućnost. Pretpostavljamo da bi se informiranjem i prezentiranjem razvojno-integrativne supervizije i njih moglo motivirati za sudjelovanje u superviziji.

Nadalje, $60 \%$ psihologinja spremno je uključiti se u obrazovanje za supervizore, iako ih je svega $9 \%$ od toga broja spremno samostalno snositi troškove tog obrazovanja.

S obzirom da većina psihologinja kontinuirano ulaže u svoje obrazovanje i većinu troškova snosi samostalno, može se pretpostaviti da će spremnije izdvojiti financijska sredstva za edukacije koje će im povećati osjećaj kompetencije u direktnom radu (poput edukacije u nekom savjetodavnom ili terapijskom pravcu). 
Ipak, ako se pronađu sredstva za edukaciju, više od polovice sudionica spremno je investirati svoje vrijeme u stjecanje supervizorskih vještina.

\section{Problem ili dilema za supervizijski susret}

Pitanje iz ovog dijela istraživanja glasilo je: „Da vam je prvi supervizijski susret zakazan za sutra, koji biste problem, dilemu ili pitanje na njega donijeli?« Pitanje je bilo otvorenog tipa te su ispitanice mogle napisati i nekoliko odgovora.

Odgovori se mogu grupirati u 5 osnovnih kategorija:

1. Konkretni problem/dilema/pitanje o radu s učenikom/roditeljem ( $34 \%$ ukupnih odgovora).

Tipična pitanja iz ove kategorije su: specifični problemi vezani uz savjetodavni rad s učenicima i roditeljima, dilema kada nije sasvim jasno tko je klijent u savjetovanju, npr. paralelno se odvija savjetovanje roditelja i učenika, problemi koje mi povjeravaju učenici i njihovi roditelji, drugo mišljenje za teže slučajeve, sumnja na seksualno zlostavljanje u obitelji, aktualni konflikt s roditeljem djeteta s posebnim potrebama, prijenos informacija dobivenih od učenika i roditelja učiteljima, ostalim stručnim suradnicima i ravnatelju, informacije dobivene od psihologa često se zloupotrebljavaju, krivo interpretiraju, ne poštuje se profesionalna ni poslovna tajna, kako razgovarati s roditeljima koji ne prihvaćaju savjetovanje u vezi poteškoća kod njihovog djeteta, kako nekim učenicima olakšati život uz njihove roditelje alkoholičare, i slično.

2. Konkretna pitanja vezana uz zakone, procedure i postupke u radu sa specifičnim klijentima (20\% ukupnih odgovora):

profesionalna tajna - koliko reći učiteljima, utvrđivanje problema s učenjem - koje testove upotrijebiti, kako doći do testova i kako primijeniti rezultate, vođenje obvezne dokumentacije, smije li se raditi opservacija prije upisa u prvi razred, nedorečenost raznih pravilnika koji se mogu različito tumačiti i izazivaju sukobe $u$ kolektivu, upotreba psihodijagnostičkih instrumenata u radu sa srednjoškolskom populacijom, što s učenicima koji dolaze u srednju školu s teškoćama u učenju, a nemaju riješenu medicinsku i psihološku dokumentaciju, uvođenje asistenta $u$ nastavi, dileme u vezi s kriterijima upisa učenika s prilagođenim programom ili individualnim pristupom u nastavi u srednje škole, kako olakšati vođenje dokumentacije, sugestije za program rada s darovitim učenicima, mora li se svako saznanje o alkoholizmu u obitelji prijavljivati centrima za socijalnu skrb, saznanja u vezi zlostavljanja u obitelji i dileme koje se javljaju kad se službeno prijavi slučaj, pitanje novog Pravilnika o radu, Povjerenstva za utvrđivanje psihofizičkog stanja i primjerenog oblika školovanja u kome je potpuno marginalizirana psihologijska struka itd. 
3. Pitanja vezana uz odnose u radnoj sredini (18\% ukupnih odgovora):

kako poboljšati komunikaciju s distanciranim nastavnicima, suradnja s nastavnicima koji su vrlo tvrdi i kruti u svojim stavovima i nisu spremni prihvatiti osobnu odgovornost, o uspostavljanju kvalitetnijeg odnosa s novom ravnateljicom, međuinstitucionalna suradnja psihologa - nerazumijevanje kliničkih psihologa i nemogućnost suradnje, o poboljšanju suradnje s centrom za socijalnu skrb, o odnosima s drugim stručnim suradnicima u školi i o njihovim nadležnostima, tj. o "petljanju« u naš posao, o savjetima kako se »pismeno« osigurati od ravnatelja koji se ponaša kao tiranin, i sl..

4. Pitanja vezana uz osobni razvoj ( $18 \%$ ukupnih odgovora):

postavljanje granica u odnosu s klijentima, stres na radnom mjestu, na koji način održati svoj mir i ne dopustiti da nas teški problemi u školi previše opterete, smanjivanje profesionalne osamljenosti, o nedostatku motivacije za pisanje magistarskog rada, kako se nositi s tolikom količinom gluposti i neznanja u prosvjeti, osobnom jačanju u odnosu na neprijateljske odnose i podmetanja od strane ravnatelja i nekih suradnika, emocionalnoj filtraciji svih loših iskustava nakupljenih tijekom godine, distanciranju od problema učenika koje ne mogu sama riješiti, provjeriti je li moj osjećaj »izgorenosti« na kraju godine normalan i sl.

5. Pitanja vezana uz nejasnoću uloge školskog psihologa (10\% ukupnih odgovora):

profesionalna odgovornost školskog psihologa (opseg poslova, ograničenja i mogućnosti, profiliranje psihologa u odnosu na ostale stručne suradnike), o rasterećenju posla psihologa, što je posao psihologa, što pedagoga, što defektologa, a što nekog drugog, o zadacima koji nisu naše struke, a ravnatelj mi ih zadaje, prevelika odgovornost i obim posla i obaveza izvan moje profesije, o tome kako mjeriti rezultate svog rada jer su oni uglavnom nemjerljivi, pozicija psihologa u odnosu na druge djelatnike, prava psihologa, i sl.

Iz odgovora na ovo pitanje otvorenog tipa vidljivo je da većina psihologinja ima neki problem/pitanje ili dilemu o kojoj bi željela govoriti na superviziji. Svega 9 (6\%) sudionica nije odgovorilo na pitanje ili je napisalo: »Ne znam, s obzirom da je kraj školske godine.« Najviše odabranih supervizijskih pitanja odnosi se na neki konkretan slučaj, no velik je broj pitanja koja se tiču nejasnoća oko primjene zakona ili određenih procedura u postupanju s nekim specifičnim grupama učenika.

$\mathrm{U}$ istraživanju iskustava sa supervizijom djelatnika u sustavu odgoja i obrazovanja (Pregrad i Krivičić Jedrejčić, 2012.) najčešće teme i pitanja koja su oni iznosili na supervizijskim susretima uključivala su različite međuljudske pa zatim institucionalne odnose. Na prvom mjestu bili su odnosi s roditeljima i kolegama, zatim odnosi s učenicima i nadređenima te odnosi s drugim ustanovama u školskom

\section{6 članci}


okruženju. Kod grupe supervizanata koja je uključivala samo stručne suradnice, najčešće teme uključivale su odnose $s$ kolegama, zatim odnose $s$ nadređenima i tek onda odnose s roditeljima i učenicima. Zanimljivo je vidjeti kako se kao pitanje za superviziju školskim psihologinjama najčešće pojavljuje neko pitanje vezano za konkretan rad s učenicima ili roditeljima, dok su iskustva iz prakse da stručne suradnice najčešće dolaze na superviziju s potrebom za radom na odnosima unutar radne sredine. Može se pretpostaviti da su, zbog svoje specifične uloge, stručnim suradnicima loši odnosi s kolegama kontinuirani izvor nezadovoljstva i stresa koji u velikoj mjeri utječe na opću učinkovitost na poslu.

\section{Ograničenja i praktične implikacije istraživanja}

Važno ograničenje ovog istraživanja je pristranost dobrovoljnog pristanka. Od ukupno poslanog broja upitnika, otprilike $50 \%$ psihologinja pristalo je sudjelovati $\mathrm{u}$ istraživanju. lako toliki odaziv može govoriti o reprezentativnosti uzorka, jednako tako može se pretpostaviti da se sudionice, koje su pristale sudjelovati u istraživanju, sustavno razlikuju od onih koje to nisu učinile. Moguće je da sudionice koje imaju manje iskustva u radu s računalima imaju određeni otpor prema takvom tipu istraživanja. Svega $9 \%$ sudionica u istraživanju je starije od 50 godina, a jedan od razloga tomu može biti to što osobama starije dobi ne odgovara digitalan oblik upitnika.

Osim kvantitativnog istraživanja kojim su dobiveni neki osnovni pokazatelji, za dublje razumijevanje problematike moglo bi se provesti niz kvalitativnih istraživanja. Kvalitativnom metodologijom, fokusnim grupama ili intervjuima, valjalo bi dubinski istražiti znanja o superviziji, motivaciju za uključivanje te očekivanja i strahove vezane za sudjelovanje u supervizijskim grupama. To se posebno odnosi na psihologinje koje nisu imale iskustvo sa supervizijom. One psihologinje koje su imale iskustvo sudjelovanja u superviziji mogu biti koristan izvor podataka o prednostima i poteškoćama na koje su nailazile, te o specifičnostima supervizije u obrazovnom kontekstu.

Takvim kvalitativnim istraživanjem mogle bi se zahvatiti suptilnije nijanse odgovora koje nije moguće vidjeti samo kvantitativnim metodama. Na osnovi tih rezultata dobila bi se jasnija slika o specifičnim potrebama školskih psihologinja.

Kao što je već ranije spomenuto, stručnjaci koji se redovito i primjereno superviziraju osjećaju se kompetentnijima u obavljanju posla, imaju veću jasnoću oko profesionalnih uloga, imaju prostor za »ventiliranje« nakupljenih emocija i dobivaju profesionalnu podršku. Zato je važno već na studiju educirati stručnjake iz područja mentalnog zdravlja o superviziji. Drugim riječima, trebalo bi upoznati buduće studente/ice psihologije i ostalih srodnih struka, s osnovama supervizijskog proce- 
sa i koristi koje on donosi. Na taj način mogu se smanjiti pogrešna očekivanja, predrasude i interpretacije pojma supervizije i budući profesionalci mogu proaktivnije poduzimati korake za profesionalnu samozaštitu.

Nadalje, bilo bi dobro omogućiti što većem broju školskih psihologinja sustavno iskustvo razvojno-integrativne supervizije. $U$ istraživanju Schneidera i Mullera (1995., prema Bezić, 2007.) određen broj ispitanika navodi strahove vezane uz superviziju, prvenstveno strah od izlaganja (prelaženje osobnih granica, neprimjereno izlaganje samog sebe, nepridržavanje pravila da se izvan grupe ne govori o onome što je na superviziji bilo rečeno) i od destruktivne kritike. Tome vjerojatno pridonosi i sama riječ koja može asocirati na neki oblik procjene i nadzora. Kako bi školske psihologinje osvijestile prednosti supervizije i potrebu za takvim oblikom usavršavanja, važno je da »na vlastitoj koži« osjete sve pozitivne učinke koje supervizija donosi. Istraživanja pokazuju da psihologinje, koje imaju iskustvo kliničke (razvojno-integrativne) supervizije, superviziju procjenjuju mnogo važnijom za profesionalni i osobni razvoj, nego psihologinje koje nisu imale to iskustvo. Jednako tako, one koje prolaze redovitu superviziju zadovoljnije su ishodima, nego one sa samo sporadičnim iskustvima supervizije (Chafouleas, Clonan i Vanauken, 2002.).

Nakon što se određenom broju školskih psihologinja omogući sustavno iskustvo razvojno-integrativne supervizije, sljedeći korak bio bi poticanje za uključivanje u obrazovanje za supervizora. Tek kada se stvori kritična masa kompetentnih supervizora, može se sustavno promicati ideja o kontinuiranoj superviziji kao obliku stručnog usavršavanja. lako je inicijativa za edukaciju supervizora u području obrazovanja već pokrenuta, educirani su ljudi koji nisu zaposleni u školama nego u Agenciji za odgoj i obrazovanje. To može kod određenog broja ljudi stvoriti ranije spomenutu asocijaciju na kontrolu i nadzor zbog uloge same institucije. Osim toga, istraživanja u drugim zemljama pokazala su da su školske psihologinje najzadovoljnije supervizijom koju im pruža osoba iste struke i radnog iskustva.

$\mathrm{U}$ trenutku kada se stvori kritična masa supervizora koji bi pokrivali područje naše zemlje, trebalo bi pokrenuti i inicijative za uvođenje supervizije u obrazovni sustav kao mogućnost kontinuiranog usavršavanja za stručne suradnike i nastavnike u okviru njihovog radnog vremena. Drugim riječima, važno je senzibilizirati ravnatelje i tijela koja donose zakone da je supervizija dio radnog procesa, a ne privatna stvar stručnjaka.

\section{LITERATURA}

1. Ajduković, M. \& Ajduković, D. (2004). Model evaluacije i učinci projekta uvođenja supervizije u sustav socijalne skrbi. Ljetopis Studijskog centrasocijalnog rada, 14 (1), 5-42.

\section{8 članci}


2. Ajduković, M. \& Cajvert, Lj. (2001). Supervizija psihosocijalnog rada kao specifični oblik profesionalnog razvoja stručnjaka u sustavu socijalne skrbi. Ljetopis Studijskog centra socijalnog rada, 8 (2), 195-214.

3. Bloomquist, A. (2007). Job satisfaction and intern supervision among school psychologist; A study for school psychologists and other social scientists. Saarbrucken: VDM Verlag Dr. Müller.

4. Bezić, I. (2007). Supervizija kao način razvijanja samopouzdanja i sposobnosti podnošenja konfrotacije. Ljetopis socijalnog rada, 14 (2), 443-452.

5. Bokulić, Z. (2003). Supervizija i njezino uvođenje u hrvatski školski sustav. Zbornik radova Sabora pedagoga Hrvatske, Hrvatski pedagoško-književni zbor, 444-450.

6. Chafouleas, S. M., Clonan, S. M. \& Vanauken, T. L. (2002). A national survey of current supervision and evaluation practices of school psychologists. Psychology in the Schools, 39 (3), 317-325.

7. Çoban, A. (2004). The effect of structured peer consultation program on different dimensions of school counseler burnout. Dissertation. Ankara: The Graduate School of Social Sciences of Middle East Technical University.

8. Coster, J. S. \& Schwebel, M. (1997). Well-functioning in professional psychologists. Professional Psychology: Research and Practice, 28, (1), 5-13.

9. Crespi, T. D. \& Fischetti, B. A. (1997). Clinical supervision for school psychologists, bridging theroy and practice. School Psychology International, 18, 41-48.

10. Dunn, R. L. (2004). The knowledge and competencies of effective school counselor supervision. Dissertation. Columbus: The Ohio State University.

11. Harvey, V. S., Pearrow, M. (2010). Identifying challenges in supervising school psychologists. Psychology in the schools, 47 (6) 567-581.

12. Harvey, V. S. \& Struzziero J. A. (2008). Professional development and supervision of school psychologists: From intern to expert (2nd edition). Thousand Oaks, CA: Corwin Press.

13. Huebner, E. S. (1993). Burnout among school psychologists in the USA: Further data related to its prevalence and correlates. School Psychology International, 14, 99-109.

14. Linton, J. M. \& Deuschle, C. J. (2006). Meeting school counselors' supervision needs: Four models of group supervision. Journal of School Counseling, 4 (6). Preuzeto s: http://www.jsc.montana.edu/articles/v4n6.pdf (18. 12. 2011.).

15. Mclntosh, D. E. \& Phelps, L. (2000). Supervision in school psychology: Where will the future take us? Psychology in the Schools, 37 (1), 33-38.

16. McMahon, M. (2002). Structured peer group supervision by email: An option for school guidance and counselling personnel. Australian Journal of Guidance and Counselling, 12 (1), 1-10. 
17. Mesić, M. \& Ajduković, M. (2010). Pravo na superviziju psihologa u službama za mentalno zdravlje kao potreba za profesionalnim dijalogom i podrškom. U: Brlas, S. \& Gulin, M. (ur.), Psihologija u zaštiti mentalnog zdravlja. Virovitica: Zavod za javno zdravstvo »Sveti Rok« Virovitičko-podravske županije.

18. Ozorlić Dominić, R. \& Skelac, M. (2011). Uvođenje integrativne supervizije u hrvatski sustav odgoja i obrazovanja. Ljetopis socijalnog rada, 18 (2), 415-423.

19. Pregrad, J. (2006). Iskustva i izazovi uvođenja supervizije u sustav prosvjete, Ljetopis Studijskog cnetra socijalnog rada. 14 (2), 311-337.

20. Pregrad J. \& Krivičić Jedrejčić A. (2012). Iskustva u primjeni supervizije u sustavu odgoja i obrazovanja iz perspektive supervizanata i supervizora. Rad izložen na 3. hrvatskoj konferenciji o superviziji, Opatija.

21. Przytula, D. R. (2007). Who is supervising the high school counselor? Analysis of job self efficacy, job satisfaction and role analysis. Dissertation. New York: Fordham University.

22. Schroffel, A. (1999). How does clinical supervision affect job satisfaction? The Clinical Supervisor, 18 (2), 91-105.

23. Skelac, M. (2008). Razvojno-integrativna supervizija u školi. Život i škola, 19, 169-174.

24. Thielking, M., Moore, S. \& Jimerson, S. R. (2006). Supervision and satisfaction among school psychologist. School Psychology International, 27, 405-414.

25. Ward, S. B. (2001). Intern Supervision in School Psychology. School psychology international, 22 (3), 269-284.

26. Webber J. (2004). Factors affecting burnout in school counselors. Dissertation. Preuzeto s: http://scholarship.shu.edu/dissertations/411 (12.10. 2011.). 
Maja Kolega

Vesna Vlahović-Štetić

University of applied sience Vern

Zagreb

Department of Psychology

Faculty of Humanities and Social Sciences

University of Zagreb

\section{THE NEED FOR SUPERVISION OF SCHOOL PSYCHOLOGISTS IN CROATIA}

\section{SUMMARY}

The main purpose of the study was to establish the current level of experience of school psychologists with supervision and the need for this type of professional support. A total of 149school psychologists participated in the study by volunteering to fill out an online survey. (Female)Psychologists who only participate in teaching were not included in the research. The results show that $70 \%$ of participants have rated their knowledge about supervision as high. In addition, $66 \%$ of participants have had previous experience with some form of supervision. However, only $22 \%$ of them participated in supervision that was particularly intendedfor school psychologists. About $80 \%$ of surveyedpsychologists rated their need for supervision as high, whereas only $5 \%$ believe that they do not need it at all. In comparison to the psychologists who did not have any supervision experience, the ones that did do not significantly differ in their need for supervision. It was established that there is a significant positive relationship between the assessment of the level of professional loneliness and the need for supervision. Finally and as expected, their motivation for participating in supervision would be high if supervision took place during working hours, in their hometown and if participation was free of charge.

Key words: supervision, psychologists, professional training. 
